The Essential Tension: Selected Studies in Scientific Tradition and Change. By Thomas S. Kuhn. Pp.366. (University of Chicago Press: Chicago and London, 1978.) \$23; £12.95.

As a general rule, scientists are too busy with their research and of en too practically minded by temperament to pay much attention to what philosophers or his orians of science have to say about what they are or ought to be doing. When, therefore, a philosopher's views catch on - as Popper's have, and in recent years Thomas Kuhn's - it is a sure sign that he may have something sensible and helpful to say.

Kuhn's views first became known through his The Structure of Scientific Revolutions (University of Chicago Press, second edition, 1970). The Essential Tension is a little compendium of essays or contributions to learned journals which enlarge on or expound one aspect or another of his thought; as such, it makes a very useful and agreeably readable introduction to his philosophy. The "essential tension" to which Kuhn refers is between our cultural inheritance of doctrine and dogma and the occasional upheavals of opinion that inaugurate a new orthodoxy or network of received beliefs - a new "paradigm" in the terminology Kuhn has made popular.

A reader intending to use The Essential Tension as an introduction to Kuhn's thought would do well to begin with the essay entitled "Logic of Discovery or Psychology of Research". From this he will learn that the views of Kuhn and of Popper, so far from being wholly antithetical, have much in common: of course scientists think up hypotheses and propound theories to explain the goings-on of the natural world and of course they then try to find out if their ideas hold water. It is over the character of this critical process that the views of Popper and Kuhn diverge most widely. Kuhn sometimes writes as if he imputed to Popper the notion that the testing of an hypothesis is a kind of private transaction between the scientist and reality, as a result of which the hypothesis either remains on probation or is falsified. Kuhn's view is that a scientist's ideas are typically assayed by reference to the prevailing "paradigm" - the prevailing "establishment" of received beliefs and current opinions. Ordinary or "normal" science, according to Kuhn, is for the most part a matter of puzzlesolving, as far as possible within this framework of received opinion. Every so often, however, the extraordinary happens: the prevailing orthodoxy is found wanting and is supplanted rather rapidly by a new orthodoxy which constitutes a new paradigm. In a first-rate symposium devoted to the exposition and criticism of Kuhn's views (Criticism and the Growth of Knowledge, ed. I. Latakos and A. Musgrave, Cambridge University Press, 1970) - a volume that a serious student of Kuhn's views should read as a companion to the present one - J. W. N. Watkins remarks that "Kuhn sees the scientific community on the analogy of a religious community and sees science as a scientist's religion": so that the supplanting of one paradigm by another might in the spirit of this parallel be thought of as a confused and anxious period marked by shrill cries of heresy and schism.

My own view is that although Kuhn's views are in many ways psychologically illuminating, he himself is guilty - as many historians of science are - of a fault of which he has accused Popper: that of giving too much weight to great historical transformations of scientific thought and too little to what goes on in laboratories from day to day. I don't myself believe in anything quite as humdrum as 'normal science'. A scientist tends to construct his own paradigm in the form of the opinions he already holds and carries over from day to day: hypotheses favoured because they have the right kind of 'feel', for example, or through pride of possession of an idea which one was the first to have. But even this personal and most immediate paradigm is not clung to with the fervour of religious belief: I don't hold from one day to the next exactly the same opinion about any problem I am studying. A scientist's reading, discussions with colleagues and reflection on his latest experimental finding may change the climate of theorectical expectations from day to day. Little revolutions or movements of unrest are constantly in progress, and the real world of science is a kind of Maoist microcosm of continuing revolution. Kuhn, I think, envisages ordinary scientific life as something more in the nature of a settled opinion ii a world of tranquil God-fearing middle-class contentment, and some of his opinions give me the impression of being held pour èpater le bourgeois.

I do not want to represent this book as if it were in any way a pitched battle between the views of Kuhn and Popper. The comparison keeps on being made because Popper doth bestride this particular world like a Colossus. But forgetting all about comparisons, Kuhn's book is full of good things, with all the qualities to be expected in writing of a learned and highly intelligent man discoursing upon subjects of great interest and importance to scientists. I should also add that, considered as a disputant, Kuhn has the unmistakeable address of a man who, so far from wanting to score points is anxious above all else to get at the truth of matters.

Sir Peter Medawar is Head of the Transplantation Biology Section of the MRC Clinical Research Centre, Harrow, UK.

\title{
Newtonian pageant
}

Newton and Newtoniana, 1672-1975: A Bibliography. By Peter and Ruth Wallis. Pp. 362. (Dawson: Folkestone, UK, 1977.) $£ 30$.

THIS massive bibliography of writings by and concerning Isaac Newton is overwhelming in magnitude. There are 324 pages with an average of some 15-16 entries per page. This comes to more than 5,000 books and articles, as some single entries are multi-volumed series. For the scholar, here is a pageant of the influence of Isaac Newton over three centuries, presented in a bibliographical memorial that embraces works in more languages than any single individual (historian or scientist) could ever read.

Four major kinds of works are listed by Peter and Ruth Wallis. First, there are 